\title{
The Contribution of Education for Sustainable Development to Transformational Leadership among Selected Namibian School Principals
}

\author{
Alex Tubawene Kanyimba1, E. N. M. Katewa², Pamela Claassen ${ }^{3}$ \\ ${ }^{1}$ Faculty of Education, University of Namibia, Windhoek Campus, Windhoek, Namibia \\ ${ }^{2}$ Faculty of Education, University of Namibia, Rundu Campus, Rundu, Namibia \\ ${ }^{3}$ Research and Publication Office, University of Namibia, Windhoek Campus, Windhoek, Namibia \\ Email: akanyimba@unam.na, mnkatewa@gmail.com, pclaassen@unam.na
}

Received 22 December 2014; accepted 19 March 2015; published 20 March 2015

Copyright (C) 2015 by authors and Scientific Research Publishing Inc.

This work is licensed under the Creative Commons Attribution International License (CC BY). http://creativecommons.org/licenses/by/4.0/

\section{Open Access}

\begin{abstract}
There is a growing interest among educational leaders in Namibia to promote transformational leadership in schools. The aim of this paper is to report on the contribution of education for sustainable development to transformational leadership among school principals in Namibian schools. The results of the study show that education for sustainable development can be seen as a tool to promote transformational leadership because it provides an opportunity for the sharing of responsibilities, opening communication channels, and achieving change in terms of leadership as well as managing personal hygiene by learners and the wider community. The results also show that the contribution of education for sustainable development to transformational leadership is challenged by the fact that education for sustainable development is a new concept. This shows a lack of awareness, a lack of parental involvement, and a lack of teamwork and unavailability of funding. This study shows the need to run training and awareness programmes by positioning education for sustainable development at the interface of self-leadership strategies and components of transformational leadership. It also indicates that school principals need to be provided with the skills required to implement education for sustainable development. The Namibian environmental education/education for sustainable development policy and related strategy must be aligned to address the roles and responsibilities of the Ministry of Education, the Ministry of Environment, other ministries and departments, and civil society and private actors who have a stake in education for sustainable development. The rewarding of committed environmental clubs and associations is also recommended. These directions should be incorporated as a non-negotiable aspect for the contribution of education to sustainable development and transformational leadership in Namibian schools.
\end{abstract}




\section{Keywords}

\section{Transformational Leadership, Education for Sustainable Development, Environmental Education,} Natural Science Education

\section{Introduction}

The concept of transformational leadership has emerged over the past decades as one of the most popular approaches to understanding leadership effectiveness [1]. Transformational leadership captures the logic of the change and transformation process which encourages innovation, creativity and risk-taking [2]. It has the ability to raise follower task performance while also encouraging extra-role transmitted through follower reactions to a leader [3]. When applying these transformational interpretations to leadership in school settings, the foregoing assertions seem to suggest that transformational leadership promotes effectiveness in reaching the school's goals because it enhances an environment in which the roles of teachers, learners and the wider community are directed by the school leader to achieve advancement. Critics of transformational leadership may argue that innovation created in the context described above is paternalistic, gender exclusive, exaggerated and has aristocratic pretensions [4]. These critical viewpoints seem to equate transformational leadership to proselytize and promote docility among followers, because innovation is directed by the transformational leader. However, the authors of this article charge that change should promote active participation by all actors in the affairs of the school that pertain to education for sustainable development (ESD), because the latter is a notion of education that needs collective conceptualization and action, if results are to be attained. This interpretation seems to be in sync with Marks and Printy (2003) who posited that transformational leaders motivate followers by raising their consciousness about the importance of organizational goals and inspiring them to transcend their own self-interest for the sake of the organization.

The concept of transformational leadership has been the subject of systematic inquiry for several decades in many institutions around the world to reframe and describe leaders who have the ability to evaluate the potential of all followers to fulfill commitments pertaining to the mandate [1] [3] [5] [6]. However, the current transformational leadership literature does not provide a clear understanding of the generalizability and influence transformational leadership across different levels of analysis [7] [8]. The authors' view is that this scenario could be addressed in educational institutions by adopting ESD in their operations. The authors of this article posit that ESD supports transformational leadership because it is a vision on education, of which the incorporation is underpinned by altering actions and attitudes of learners, teachers and members of the wider community towards sustainable development. This approach should position school leaders to inspire and integrate the individualized concerns of teachers, learners and the wider community.

The concept of transformational leadership has been the subject of inquiry in non-school organizations [5]. It has emerged as an important approach to leadership as evidenced by the classic work of the political sociologist James MacGregor Burns in 1978 [9] [10]. Many educational institutions around the world have attempted to use the concept of transformational leadership in the operations of schools and other educational institutions [11] [12]. However, most of these initiatives mainly present the application of transformational leadership in the general context of education. What is lacking in these initiatives is the examination of the contribution of ESD to transformational leadership. This study hopes to address this hiatus by examining how ESD can contribute to transformational leadership in the Namibian schools context.

The Namibian education system was restructured following independence attained on 21 March 1990. The Namibian scholars of educational management popularized terms of participative leadership, democratic leadership and transformational leadership [13]. The emergence of these leadership concepts is a reflection of dissatisfaction with traditional and instructional leadership styles which focus on the school principal as the centre of expertise and authority on matters pertaining to curriculum planning, implementation and assessment. Moreover, the analysis of Namibian-based literature in education management does not seem to address the need for the integration of ESD in the management structures of primary and secondary schools. The aim of this study is to report on the research regarding the contribution of ESD to transformational leadership among school principals in the Namibian schools. To reach this aim, this paper is structured as follows: 
- The statement of the problem.

- The theoretical framework.

- Exposition of the research design.

- Presentation and interpretation of data.

- Discussion in view of the theoretical framework.

- Recommendations that will address the contribution of ESD to transformational leadership among school principals in Namibian secondary and primary schools.

\section{Statement of the Problem}

There is a growing interest among educational leaders to promote transformational leadership in Namibian primary and secondary schools [13]. However, the mechanisms that can be used to achieve this aim remain unclear [14]-[16]. The ESD concept can be used to promote transformational leadership in schools because it is highlighted as an education for transforming schools into being part of a sustainable society. It touches every aspect of education including planning, policy development, programme implementation, finance, curricula, teaching, learning, assessment and administration [17]. This study sought to investigate how ESD could be used to promote transformational leadership among school principals in Namibian primary, combined and secondary schools. The following research questions were addressed to facilitate understanding of the research problem:

- What are school principals’ views on integrating ESD as a vehicle for transformational leadership?

- What are challenges that school principals envisage regarding the integration of ESD as a vehicle for transformational leadership in Namibian schools?

- What are school principals' recommendations regarding the integration of ESD as a vehicle for transformational leadership in Namibian schools?

\section{Theoretical Framework}

ESD is education geared to promote environmental protection. It is seen as a transformative education process that integrates environmental, economic and social sustainability with the teaching and learning process as well as the day-to-day management of the school. Environmental sustainability includes but is not limited to risk assessment, natural resources, human and ecosystem health. Economic sustainability includes but is not limited to productivity and technological growth. It also addresses issues relating to energy production and efficiency, ecoefficiency analysis and designs for the environment. Moreover, social sustainability addresses the question of informed citizenry, stakeholder participation, social justice, environmental justice, school policy and diffusion of knowledge [18].

The study to investigate the contribution of ESD to transformational leadership among selected Namibian school principals was guided by the self-leadership leadership theory [19]. Self-leadership is a process through which people influence themselves to achieve self-direction and self-motivation necessary to perform [20]. Houghton and Yoho (2005) state that the self-leadership theory rests on three primary strategies, namely:

- Behavior-focused strategies which are designed to increase self-awareness leading to successful management of behaviors.

- Natural reward strategies designed to create situations in which a person is motivated or rewarded by the task or activity itself.

- Constructive thought pattern strategies which deal with the management of cognitive processes. It refers to the tools for shaping thinking patterns: self-analysis and improvement of belief systems and positive self-talk [20] [21].

These strategies become relevant in this context when the behavior strategies become consistent with the natural liking of social, economic and ecological dimensions of sustainable development and also when the belief systems of the self-leader changes in light of that requirement. Bligh et al. (2006) argue that members who engage in self-leadership are more likely to believe strongly in the team's goals and values and communicate those beliefs to other team members. The authors of this article are of the view that the behavior and thought process of members who embrace ESD in self-leadership strategies can inspire teachers, learners and the wider community through their actions. In this case the self-leadership strategies need not be focused on the development of individuals but can be used as a spring-board to support learners, teachers and the wider community. Yun et al. (2006) argue that self-leadership strategies are likely to facilitate empowerment by enhancing perceptions of 
meaningfulness, purpose, self-determination, competence and self-efficacy. Thus, the embracement of self-leadership strategies is not an end in itself but a means to creating empowerment. Bligh et al. (2006) argue that self-leadership is an antecedent to all other forms of leadership. In light of the aforementioned assertion, the authors of this article chose a self-leadership notion that builds on dimensions of transformational leadership into the notion of ESD. Viewed in this context, the integration of self-leadership into ESD can be used to enhance four dimensions of transformational leadership. Firstly, the idealized influence describes charismatic leaders that cause followers to identify with their vision of ESD. Secondly, inspirational motivation represents leaders whose articulate visions that appeal to followers. Next is intellectual stimulation which represents the degree to which leaders challenge assumptions, take risks and solicit followers' ideas. Finally, the individualized consideration represents the leaders attending to followers' needs, acting as mentors or coaches, and listening to followers' concerns [22].

Self-leadership strategies are relevant for this study, because they can be constituted to enhance the integration of ESD into transformational leadership in Namibian schools. This is important because self-leadership strategies prescribe behavioral and cognitive structures that an individual leader must have to augment the four dimensions of transformational leadership. For this to happen, this study embraces a self-leadership theory that adheres to the following characteristics:

- The leader develops cognitive/behavioral structures and constructive thought patterns that provide an ideal influence towards ESD.

- The leader uses the cognitive/behavioral structures and constructive thought patterns to inspire learners, teachers and the wider community towards ESD.

- The leader uses his/her cognitive/behavioral structures and constructive thought patterns to provide intellectual stimulation by challenging assumptions that are not consistent with the notion of ESD.

- To leader uses cognitive/behavioral and constructive thought patterns to consider individual views and environmental concerns of learners, teachers and the wider community.

This study was launched among a sample of selected Namibian primary, combined and secondary schools following the above theoretical framework.

\section{Research Design Methods, Strategy and Methods}

This study adopted a qualitative research method because it sought to probe the principals' views, beliefs and assumptions, understanding and experiences regarding the contribution of ESD to transformational leadership in selected Namibian schools [23] [24]. Therefore, a specific type of qualitative research method was used pertaining to phenomenology [25]. Phenomenology advocates the study of experience and sees behavior as being determined by the phenomenon of experience. The researchers chose phenomenological design because of its emphasis on the primacy of consciousness and understanding as active determinants of action.

\subsection{Population and Sampling}

The population of this study comprised all school principals in Namibian schools. The schools comprised of a combination of rural, township and urban schools with an average enrollment of approximately between 500 1200 learners. Purposeful and convenience sampling methods were applied to select respondents from the population [26]. School principals were purposefully selected because researchers believed that they could provide insight knowledge and understanding regarding the contribution of ESD to transformational leadership.

The researchers were of the opinion that participation in related courses that one of researchers had implemented previously may have enhanced principals' understanding on the subject. The principals identified using this technique were from the Hanganeni Primary School, Okalumbu and Omakondo combined schools and the Hochland and Noordgrens high schools. However, the researchers used convenience sampling to identify school principals for participation in the study although they had not been involved in prior ESD courses initiated by one of the researchers. The participating principals in this sampling category were from Kehemu, Rundu Secondary School and Hochland High School. The primary criteria for choosing these principals were that they were easy to reach and were readily available.

\subsection{Structured Questionnaire}

To answer the aforementioned research questions, a structured questionnaire was distributed to school principals 
in the Namibian primary, combined and secondary schools. The structured questionnaire consisted of openended questions which sought to explore how the schools principals assess the contribution of ESD in selected Namibian primary, combined and secondary schools. The responses to the structured questionnaire are believed to be a true reflection of principals' views at the time of collecting data.

\subsection{Data Collection Process, Analysis and Limitations}

The data was collected from school principals during the period 13 July 2014 to 4 August 2014. Permission to distribute the structured questionnaire was obtained from the Permanent Secretary of the Ministry of Education. Twenty (20) structured questionnaires were distributed to the different schools principals, of which eight (8) were returned by the principals, fully completed. This accounts for a $40 \%$ questionnaire return rate. The researchers were of the opinion that the returned structured questionnaires provided a picture that could be used to assess the contribution of ESD to transformational leadership in Namibian secondary schools.

Collected data was transcribed as written down by school principals and analyzed using an interpretative phenomenological analysis with an idiographic focus [27]. The data analysis approach was essential for this study because it assessed and interpreted the personal views of the participants. It also offered insights into how individual school principals in a given context interpret the phenomenon of ESD.

There are two major limitations that may have affected the results of this study. For most school teachers and principals in Namibia, ESD is new concept over which they may have little understanding. This made it difficult to adequately respond to the questions. Other school principals did not complete the structured questionnaires as requested, even after having been assured of anonymity, because they believed that they were not involved in ESD. Despite these limitations, the researchers believe that these study represent an accurate presentation of the school principals' understanding of ESD in the own setting.

\section{Presentation and Interpretation of Data}

The data collected shows the ways in which the integration of ESD in a school's principal leadership contribute to transformational leadership at school. It also shows the challenges that school principals envisage in the use of ESD as a vehicle for transformational leadership. Finally, it presents suggested measures that school principals could put in place to ensure that ESD becomes a vehicle for transformational leadership at school.

\subsection{Ways in Which the Integration of ESD in a School Principal's Leadership Could Contribute to Transformational Leadership in Namibian Schools}

The following responses emerged from the corpus of principals' narratives:

School principal 1\# It provides an opportunity for even distribution of tasks among the school community (learners and parents). Education for sustainable development paves ways for the principal to guide and lead the way towards the vision where the school should be in the future, making it easier for the integration of education for sustainable development activities to be implemented.

School principal 2\# Improve the school management of scare resources such as water; improve or look after the plants; improve our use of littering materials e.g. recycling and others, help transform our leadership and maintain sustainable use of energy e.g. lights, geysers etc.; it will even impact or improve our immediate communities and our families.

School principal 3\# The followers will be encouraged to explore new ways of doing things and new opportunities to learners. The principal will always keep lines of communication open so that the followers (learners, teachers, wider community) feel free to share their ideas so that he leads and can give unique contribution. The principal will have a clear vision that will shape or articulate the followers. The principal serves as a role model for the followers, trust and respect him/her.

School principal 4\# By delegating this programme to teachers and learner; by giving the maximum support to the teachers and learners involved in the programme.

School principal 5\# To prepare learners as future leaders, to instill hygiene amongst learners, to know the importance of protecting the environment for future generations.

School principal 6\# Passion of keeping environment clean and promote hygiene at school; instill the sense of responsibility within the learning community; improve teaching and learning; creates a conducive for 
environment and preserve resources.

School principal 7\# Leadership is not stagnant, it evolves as time changes, leadership is about change and change is inevitable, a leader that cares about the environment cares about the individual that lives/resides in that environment; as the environment changes, it also changes, and it also affects the mindset/well-being of the residents to change positively.

School principal 8\# Raising environmental awareness, reduction in poverty, creating jobs (self-employment), possible reduction in pregnancy rates.

The excerpts above show ways in which the integration of ESD could support transformational leadership. These are sharing of responsibilities, opening communication channels, and achieving change in terms of leadership and also in the managing of natural resources in the school. The other suggestion is that ESD could contribute to transformation through awareness about environmental issues. These suggestions can lead to and developing of individualized consideration.

\subsection{The Challenges That Schools Principals Envisage in the Use of ESD as a Vehicle for Transformational Leadership in Namibian Schools}

The following responses emerged from the corpus of principals' narratives:

School principal 1\# For most teachers at school this is a new concept and they have little understanding or no understanding at all about education for sustainable development, making it difficult for them to engage fully in education for sustainable development activities. Some educators might be already involved in education for sustainable development activities but they are not aware that what they are involved with is education for sustainable development activities.

School principal 2\# Convincing everyone to understand the necessities of these Environmental Educations (EES). Monitoring and controlling those who are around. Keeps it going as long as we shall live.

School principal 3\# Misuse of influence: if the principal acts immorally or unethically... without establishing procedures for the acknowledgment and accepting failures, the strategies can cause you to pursue ideas with little or no merit. Over emphasis on some of same individual without balancing could over emphasize the needs or contribution of a single member.

School principal 4\# The time to conduct/integrate this programme might not be enough as most of the time is utilized with academic work. The response from the community will determine the success of the whole programme.

School principal 5\# Lack of parental involvement; lack of resources and equipment, lack of commitment.

School principal 6\# Team work, commitment and dedication and time; availability of funds.

School principal 7\# Change is not always easily attained, the recipients must first understand and learn the aims/objectives of the changes to be undertaken, challenges such as time frame, participation will be a key vehicle for transformation.

School principal 8\# Lack of interest and support from learners, teachers and community, lack of resources.

A number of challenges in the use of ESD as a vehicle for transformational leadership are outlined in the above excerpts. The ones that stand out are that ESD "is a new concept" and "lack of team work". The other challenges pertain to difficulties associated with convincing everyone to understand ESD and also lack of interest and support from learners, teachers and the community. These suggestions seem to affect transformational leadership because they express some of the assumptions that need to be addressed to enact change among school learners, teachers and the community.

\subsection{The Measures That School Principals Could Put in Place to Ensure That ESD Becomes a Vehicle for Transformational Leadership in Namibian Schools}

The following responses emerged from the corpus of principals' narratives:

School principal 1\# School based Professional development for staff to create awareness; involvement of parents and learners in education for sustainable development activities to enhance learning and participates in decision making for example education for sustainable development committees; staff members to participate in short courses about education for sustainable development; participate in national and in- 
ternational conferences on education for sustainable development for capacity building and networking purposes.

School principal 2\# Establish a steering committee; seeing to it that all in the committee are convinced and motivated; seeing to it that subcommittees such as EE clubs, class groups are also convinced and motivated; basically let everyone to do the right thing.

School principal 3\# Develop a challenging and attractive visions, together with the teacher/ employees; the vision to a strategy for its achievement; develop the visions, specify and translate into action, express confidence decisiveness and optimist about the vision through small planned steps and small succession path for its full implementations.

School principal 4\# More support from the Ministry of Environment, the main target should be learners in lower grades so that they are armed with the knowledge of education for sustainable development.

School principal 5\# Establish a committed environmental club, involve all stakeholders, and reward the most active participants.

School principal 6\# Proper programme, action plan and monitoring and evaluation of programme.

School principal 7\# Goals/aims objectives must be clearly outlined for all to see and understand.

School principal 8\# Regular meetings, school workshops, motivational talks and competitions, possible creation of periods for education for sustainable development in the curriculum.

The measures that school principals could put in place to ensure that ESD becomes a vehicle for transformational leadership were outlined. It seems that visioning, awareness creation and establishing committees to address environmental issues in the school are important in this regard. The need to support ESD was also identified. It seems that principals view the need for more support relating to the contribution of ESD to transformation leadership to have to come from the Ministry of Environment and Tourism.

\section{The Discussions}

This study provided an opportunity to obtain the views of school principals regarding the contribution of ESD to transformational leadership in Namibian schools. The self-leadership strategies guided the study because its strategies need to be developed before principals are able to engage in transformational leadership. The selfleadership strategies aid the process of inspiring, stimulating and integrating individual teachers, learners and wider community concerns pertaining to environmental, economic and social sustainability.

\subsection{Ways in Which the Integration of ESD in School Principals' Leadership Could Contribute to Transformational Leadership in School}

Participants in the study suggested that ESD could enact transformational leadership at schools. Based on data presented in the empirical part of the report, it can be concluded that ESD could contribute to transformational leadership because:

- It provides an opportunity for everyone to be involved in environmental protection through ESD.

- It provides an opportunity for the school principal to create awareness about ESD.

- It provides an opportunity for the school principal to open channels of communication related to ESD.

- It provides an opportunity for school learners to promote personal hygiene by embracing the vision of ESD.

The above contributions of ESD to transformational leadership are consistent with the propositions of Fullan (2004); Lozano (2006) and Ferrer-Balas et al. (2008). It is stated in these publications that transformational leadership promotes the necessary change accompanied by the proper assignment of responsibility [28]-[30]. The promotion of awareness is also consistent with the concept of sustainability which requires continuous improvement, adaptation and collective problem-solving in the face of complex challenges that keep on arising [28]. Moreover, transformational leadership pertains to the societal problem-solving orientation in education and research through an interaction with multiple interfaces to be pertinent to societal goals. As a result, learners as well as teachers and community members must be able to deal with the complexities of real problems and the uncertainties associated with the future [30].

The results of the study seem to suggest that ESD could be used to develop transformational leadership at school. However, this process needs school principals to engage learners, teachers and the wider community to develop awareness and essentially open channels of communication through proper assignment of responsibility pertaining to environmental, economic and social problem-solving. In that regard, school leadership that chooses 
this channel of ESD to enact transformational leadership needs to have an understanding of the notions of education in relation to sustainable development.

\subsection{The Challenges That Schools Principals Envisage Regarding the Integration of ESD as a Vehicle for Transformational Leadership in Their Schools}

The school principals who participated in this study identified a number of challenges that school principals may encounter in utilizing ESD as a vehicle for transformational leadership at school. These challenges relate to the fact that ESD is a new concept, that there is a lack of awareness, a lack of parental involvement, a lack of teamwork and unavailability of funding. The results are consistent with the study of Velazquez, Munguia and Sanchez (2005) in which it is argued that lack of involvement and participation among notable administrators and among students, staff, and even surrounding communities are hindrances to ESD [31]. Based on the results of the study the following conclusions can be made about challenges that school principals envisaged in the use of ESD as a vehicle for transformational leadership:

- It is important to coach school principals in Namibia to understand the concept of ESD and transformational leadership.

- The school principals should be coached to link the ESD concepts to their own behavior by being exemplary in their vision and inspiration.

- They should be coached on how to foster team work, not only among school learners and teachers but also within the surrounding community.

- They should be coached on how to mobilize resources for the effective implementation of ESD.

The above requirements are important in developing an understanding of ESD among school principals. This seems to augment the responsibilities of educators outlined by Scott (2002). The author maintains that educators help learners (also community members) understand why the idea of sustainable development ought to be of interest to them; to help learners gain plural perspectives on issues from a range of cultural stances and to provide opportunities for an active consideration of issues through appropriate pedagogies which, for example, might begin from learners' and teachers' different interests, and to encourage pupils to continue to think about what to do, individually and socially, and to keep their own and other people's options [32]. However, the results of the study expand on this notion because they seem to suggest that educators need to develop their behavior consistent to the notion of ESD and need to have the ability for resource mobilization.

\subsection{The Measures That School Principals Could Put in Place to Ensure That ESD Becomes a Vehicle for Transformational Leadership in Their Schools}

The school principals who participated in this study identified measures that school principals could put in place to ensure that ESD becomes a vehicle for transformational leadership in their schools. Based on the data presented in the empirical part of this report, the following conclusions can be madein this regard:

- There is a need to create awareness through the provision of short courses on ESD.

- The awareness process must articulate the goals and objectives of ESD.

- The awareness should articulate the role of ESD concepts and explain how to devise the programmes and action plan.

- The awareness mechanism should include the monitoring and evaluation programme of the relationship between ESD and transformational leadership in the school.

- There is a need to reward environmental clubs and associations that make a difference with regard to ESD.

- There is a need to enhance the involvement of the Ministry of Environment and Tourism.

The measures that could be put in place to ensure that ESD becomes a vehicle for transformational leadership have also been discussed in the literature. Ferrer-Balas et al. (2008) express the presence of "connectors", "existence of coordination bodies and projects", and "availability of funding" [30]. The literature seems to suggest the need to establish a framework and also financial means that can drive the implementation of ESD in transformational leadership. The results of this study expand on this notion by suggesting the provision of awareness, development of programmes and action plans and also setting up monitoring and evaluation measures for ESD.

\section{Recommendations and Policy Implications}

The interest of this study was to investigate the contribution of a transformational leadership model on ESD in 
Namibian schools. The first step in highlighting the contribution of ESD to transformational leadership in Namibian secondary schools is to coach school principals to be role models on aspects of ESD. This is possible if the coaching of school principals promotes how ESD could be built at the interface of interaction between strategies of the self-leadership model and transformational model of leadership. This is important because it would encourage school principals of Namibian schools to develop behavior that promotes ESD and to link it to the managing of their schools. It would furthermore encourage a natural interest for ESD to develop and allow school principals to engage in the constructive processes that promote the development of the vision of ESD. However, it is argued that the development of self-leadership strategies is not an end in itself but should be the means to an end. This means that in order to use ESD to develop transformational leadership one must first have self-leadership that constitutes sustainable development characteristics. Crossan, Vera and Nanjad (2007) argue that without leadership of the self, the leader's potential for dealing with complex issues requiring deep judgment is limited [33]. This approach is important because it seems to position ESD at the interface of self-leadership strategies and components of transformational leadership.

In view of the above, the principals should be coached to position ESD at the interface of self-leadership strategies and the four dimensions of transformational leadership in the school. This process is likely to ensue in the following ways: firstly, educators should be coached in their own behavior to provide an idealized influence by being charismatic leaders and by causing learners, teachers and the wider community to identify with their vision of ESD. They should use their own behavior to provide inspirational motivation by articulating ESD visions which appeal to learners, teachers and the wider community. They should furthermore use their own constructive thought processes to provide intellectual stimulation by challenging assumptions, taking risks and soliciting followers' ideas in relation to ESD. They should use their own constructive thought process to provide individualized consideration of learners' and teachers' needs and to challenge assumptions which are not consistent with the notion of ESD. The researchers of this article believe that this process places ESD at the interface of self-leadership and transformational leadership.

The results of the study show that one of the challenges to the contribution of ESD to transformational leadership is the shortage of resources. This is justified by Thomas (2004), who shows that lack of financial resources and resource support also affect programmes on sustainable development [34]. It is therefore recommended that the training and creating of awareness to enhance the contribution of ESD to transformational leadership must engage school principals on how to mobilize resources needed to support ESD programmes in their respective schools.

The school principals who participated in this study called for the need to enhance the participation of the Ministry of Environment and Tourism in the development of ESD and transformational leaderships at schools. However, the researchers also support the need to enhance the multiple relationships between Ministries of Education, Environment and other ministries and departments that have a stake in education in relation to sustainable development. This need to be augmented by the Namibia's guiding documents on ESD. For example, the present strategy on ESD has shortcomings because it describes roles and responsibilities that should exist between the Ministry of Education (MoE) and Higher Education Institution (HEI), National Training Authority (NTA), media, private sectors, bilateral and multilateral partners and civil society in the implementation of ESD [35]. In that regard, the researchers recommend that the ESD strategy for Namibia must be aligned to develop an institutional framework for the implementation of ESD that describes roles and responsibilities of the different ministries and the other partners mentioned therein. Furthermore, the Professional Quality Assurance (PQA) unit is mentioned in the strategy and this unit needs to focus on ESD as the basis for transformational leadership in Namibian schools. The PQA unit supports quality and hence it needs to support the creation of training and learning environments that see the need for ESD as a tool for both quality and transformational leadership among principals of Namibian schools. Lastly, the policy on environmental education/education for sustainable development must be aligned to support the provision of ESD as a non-negotiable aspect of quality leadership among Namibian school principals.

The rewarding of committed environmental clubs and school principals that promote ESD is important. Shephard (2006) argues that the best approach is for educators to be open about their intended learning outcomes and to reward attainment of these outcomes [36]. Moreover, Moore (2005) highlights the need to create incentives for educators to engage and support implementation of ESD in their classrooms [37]. This is one of the important steps in the implementation of ESD as the basis for transformational leadership. It helps to suppress the feeling of isolation among principals, educators and acknowledges that their efforts are being observed and 
rewarded. This recommendation must form an important part of the resource mobilization process.

\section{Conclusion}

This paper demonstrates the contribution of ESD to transformational leadership in Namibian schools. The results of the study show that ESD contributes to transformational leadership because it provides an opportunity for sharing responsibilities and for school principals to create awareness about ESD. Moreover, school principals will have an opportunity to open channels of communication in relation to ESD while learners will have an opportunity to promote personal hygiene by embracing the vision of ESD. Through these attitudes transformation leadership is likely to be developed. Self-leadership theory is an important conceptual framework to guide the contribution of ESD to transformational leadership, because it helps the school principal to develop behavior and thoughts which can be used in the implementation of systemic linkages of the environment among learners and the wider community. If ESD is integrated at the interface of the interaction of self-leadership into transformational components, they are likely to facilitate empowerment and enhance the determination to address not only environmental challenges but also transformational leadership challenges.

\section{References}

[1] Bass, B.M. (1999) Two Decades of Research and Development in Transformational Leadership. European Journal of Work and Organizational Psychology, 8, 9-32. http://dx.doi.org/10.1080/135943299398410

[2] Burns, J.M. (1978) Leadership. Harper and Row, New York.

[3] Piccolo, R.F. and Colquitt, J.A. (2006) Transformational Leadership and Job Behaviors: The Mediating Role of Core Job Characteristics. Academy of Management Journal, 49, 327-340. http://dx.doi.org/10.5465/AMJ.2006.20786079

[4] Gronn, P. (1995) Greatness Revisited: The Current Obsession with Transformational Leadership. Leading and Managing, 1, 14-27.

[5] Marks, H.M. and Printy, M.S. (2003) Principal Leadership and School Performance: An Integration of Transformational and Instructional Leadership. Educational Administration Quarterly, 39, 370-397. http://dx.doi.org/10.1177/0013161X03253412

[6] Fernandes, C. and Awamleh, R. (2007) The Impact of Transformational and Transactional Leadership Styles on Employee's Satisfaction and Performance: An Empirical Test in a Multicultural Environment. International Business \& Economics Research Journal, 3, 65-76.

[7] Wang, G., Oh, I., Courtright, S.H. and Colbert, A.E. (2011) Transformational Leadership and Performance across Criteria and Levels: A Meta-Analytic Review of 25 Years of Research. Group \& Organization Management, 36, $223-270$. http://dx.doi.org/10.1177/1059601111401017

[8] Hoffman, B.J., Bynum, B.H., Piccolo, R.F. and Sutton, A.W. (2011) Person-Organization Value Congruence: How Transformational Leaders Influence Work Group Effectiveness. Academy of Management Journal, 54, 779-796. http://dx.doi.org/10.5465/AMJ.2011.64870139

[9] Vinger, G. and Cillier, S. (2006) Effective Transformational Leadership Behaviours for Managing Change. SA Journal of Human Resource Management, 4, 1-9. http://dx.doi.org/10.4102/sajhrm.v4i2.87

[10] Birasnav, M., Rangnekar, S. and Dalpati, A. (2011) Transformational Leadership and Human Capital Benefits: The Role of Knowledge Management. Leadership \& Organization Development Journal, 32, 106-126. http://dx.doi.org/10.1108/01437731111112962

[11] Nash, S.D. (2012) What Makes a Transformational Education Leader? An Investigation into the Antecedent Experiences of k-12 Transformational Leadership. Unpublished Doctoral Thesis, Montana State University, Bozeman.

[12] Callow, N. (2011) Transformational Leadership in Higher Education Resource Guide. http://www.heacademy.ac.uk/assets/hlst/documents/resource_guides/transformational-leadership.pdf

[13] Auala, R., Mushaandja, J. and Amukugo, E. (2011) Managing Change: Advanced Diploma in Educational Leadership and Management. Centre for External Studies, Windhoek.

[14] Leithwood, K. (2007) Transformational School Leadership in a Transactional Policy World. In: Jossey-Bass, Ed., Jossey-Bass Reader on Educational Leadership, John Wiley \& Sons, San Francisco, 183-196.

[15] Hallinger, P. (2003) Leading Educational Change: Reflections on the Practice of Instructional and Transformational Leadership. Cambridge Journal of Education, 33, 329-352. http://dx.doi.org/10.1080/0305764032000122005

[16] Goddard, J. (2003) Leadership in the (Post) Modern Era. In: Bennett, B. and Anderson, L., Eds., Rethinking Educational Leadership, Sage, Thousand Oaks, 11-26. 
[17] Sipos, Y., Battisti, B. and Grimm, K. (2008) Achieving Transformative Sustainability Learning: Engaging Head, Hands and Heart. International Journal of Sustainability in Higher Education, 9, 68-86. http://dx.doi.org/10.1108/14676370810842193

[18] Mihelcic, J.R., Phillips, L.D. and Watkins Jr., D.W. (2006) Integrating a Global Perspective into Education and Research: Engineering International Sustainable Development. Environmental Engineering Science, 23, 426-438. http://dx.doi.org/10.1089/ees.2006.23.426

[19] Yun, S., Cox, J., Henry, P. and Sims Jr., H.P. (2006) The Forgotten Follower: A Contingency Model of Leadership and Follower Self-Leadership. Journal of Managerial Psychology, 21, 374-388. http://dx.doi.org/10.1108/02683940610663141

[20] Bligh, M.C., Pearce, C.L. and Kohles, J.C. (2006) The Importance of Self- and Shared Leadership in Team Based Knowledge Work: A Meso-Level Model of Leadership Dynamics. Journal of Managerial Psychology, 21, 296-318.

[21] Houghton, J.D. and Yoho, S.K. (2006) Toward a Contingency Model of Leadership and Psychological Empowerment: When Should Self-Leadership Be Encouraged? Journal of Leadership and Organizational Studies, 11, 66-83.

[22] Eagly, A.H., Johannesen-Schmidt, M.C. and Van Engen, M.L. (2003) Transformational, Transactional, and LaissezFaire Leadership Styles: A Meta-Analysis Comparing Women and Men. Psychological Bulletin, 129, 569-591. http://dx.doi.org/10.1037/0033-2909.129.4.569

[23] Wilson, E. (2009) School Based Research: A Guide for Education Students. SAGE, London.

[24] Creswell, J.W. (2012) Educational Research: Planning, Conduction and Evaluation Quantitative and Qualitative Research. 4th Edition, Pearson, London.

[25] Cohen, L., Marion, L. and Morrison, K. (2011) Research Methods in Education. 7th Edition, Routledge, London.

[26] Neuman, W.L. (2011) Social Research Methods: Qualitative and Quantitative Approaches. 7th Edition, Pearson, Boston.

[27] Ary, D., Jacobs, L.C., Sorensen, C.K. and Walker, D. (2014) Introduction to Research in Education. 9th Edition, Wadsworth, London.

[28] Fullan, M. (2004) Prepared for Hot Seat, Urban Leadership Community, England. Ontario Institute for Studies in Education, University of Toronto, Toronto.

[29] Lozano, R. (2006) Incorporation and Institutionalization of SD into Universities: Breaking through Barriers to Change. Journal of Cleaner Production, 14, 787-796. http://dx.doi.org/10.1016/j.jclepro.2005.12.010

[30] Ferrer-Balas, D., Adachi, J., Banas, S., Davidson, C.L., Hoshikoshi, A., Mishra, A., Motodoa, Y., Onga, M. and Ostwald, M. (2008) An International Comparative Analysis of Sustainability Transformation across Seven Universities. International Journal of Sustainability in Higher Education, 9, 295-316. http://dx.doi.org/10.1108/14676370810885907

[31] Velazquez, L., Munguia, N. and Sanchez, M. (2005) Deterring Sustainability in Higher Education Institutions. International Journal of Sustainability in Higher Education, 6, 383-391. http://dx.doi.org/10.1108/14676370510623865

[32] Scott, W. (2002) Education and Sustainable Development: Challenges, Responsibilities, and Frames of Mind. The Trumpeter Journal of Ecosophy, 18, 101-112. http://trumpeter.athabascau.ca/index.php/trumpet/article/view/123/134

[33] Crossan, M., Vera, D. and Nanjad, L. (2008) Transcendent Leadership: Strategic Leadership in Dynamic Environments. The Leadership Quarterly, 19, 569-581. http://dx.doi.org/10.1016/j.leaqua.2008.07.008

[34] Thomas, I. (2004) Sustainability in Tertiary Curricula: What Is Stopping It Happening? International Journal of Sustainability in Higher Education, 5, 33-47. http://dx.doi.org/10.1108/14676370410517387

[35] Namibia Government (2009) Education for Sustainable Development Strategy 2009-2014. Government of the Republic of Namibia, Windhoek.

[36] Shephard, K. (2008) Higher Education for Sustainability: Seeking Affective Learning Outcomes. International Journal of Sustainability in Higher Education, 9, 87-98. http://dx.doi.org/10.1108/14676370810842201

[37] Moore, J. (2005) Seven Recommendations for Creating Sustainability Education at the University Level: A Guide for Change Agents. International Journal of Sustainability in Higher Education, 6, 326-339. http://dx.doi.org/10.1108/14676370510623829 